\title{
Water relations of cork oak (Quercus suber L.) seedlings in response to shading and moderate drought
}

\author{
Marta PARdos $^{\mathrm{a} *}$, M. Dolores JimÉnEZ ${ }^{\mathrm{a}}$, Ismael ARANDA ${ }^{\mathrm{a}}$, Jaime PUÉRTOLAS ${ }^{\mathrm{b}}$, José A. PARdos $^{\mathrm{b}}$ \\ a CIFOR-INIA, Ap. Correos 8.111, 28080 Madrid, Spain

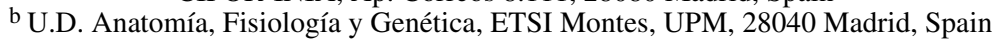

(Received 10 June 2004; accepted 29 September 2004)

\begin{abstract}
The interactive effects of light and drought on water relations and soluble sugars were addressed on Quercus suber L. seedlings grown under the combination of four irradiances and two soil water contents. Leaf water potentials at predawn and midday were lower for water stressed seedlings, independently of light environment. Osmotic potentials at full $\left(\Psi \pi_{100}\right)$ and zero turgor $\left(\Psi \pi_{0}\right)$ decreased with drought, under the four light treatments. However, the decline was greater with the development of water stress under the two treatments of higher light availability. The higher soluble sugar concentrations in seedlings grown under higher irradiances provoked a decrease of $\Psi \pi_{0}$. The decrease in $\Psi \pi_{100}$ and $\Psi \pi_{0}$ in moderate stressed seedlings was accompanied by an increase in $\varepsilon_{\max }$. The lower ability for osmotic adjustment in seedlings grown under moderate water stress and low light environment suggested a lower efficiency in developing physiological mechanisms for drought tolerance in shade-grown seedlings.
\end{abstract}

cork oak / drought / light / osmotic adjustment / soluble sugars

Résumé - Relations hydriques des semis de chêne-liège (Quercus suber L.) en réponse à l'ombre et à une sécheresse modérée. Les effets interactifs de la lumière et de la sécheresse sur les relations hydriques et les sucres solubles ont été étudiés sur des plantules de Quercus suber L. qui ont poussé sous la combinaison de quatre éclairements différents et de deux contenus en eau du sol. Les potentiels hydriques foliaires mesurés l'un avant l'aube et l'autre à midi étaient plus bas pour les plantules subissant un stress hydrique indépendamment du niveau d'éclairement. La pression osmotique à pleine turgescence $\left(\Psi \pi_{100}\right)$ et la pression osmotique à turgescence nulle $\left(\Psi \pi_{0}\right)$ ont diminué avec la sécheresse sous les quatre éclairements. Cependant, les diminutions étaient plus grandes pour les plantules soumises à un stress hydrique et à un éclairement élevé. La plus grande concentration de sucres solubles des plantules ayant poussé sous un plus grand éclairement a provoqué la diminution de $\Psi \pi_{0}$. La diminution de $\Psi \pi_{100}$ et de $\Psi \pi_{0}$ pour les plantules ayant poussé sous une sécheresse modérée a été accompagnée d'une augmentation de $\varepsilon_{\max }$. La moindre capacité pour l'ajustement osmotique des plantules ayant poussé sous un stress hydrique modéré et une faible intensité lumineuse a montré une plus faible efficacité pour le développement des mécanismes physiologiques de tolérance à la sécheresse de ces plantules ayant poussé à l'ombre.

chêne-liège / sécheresse / lumière / ajustement osmotique / sucres solubles

\section{INTRODUCTION}

Light $[10,48,52]$ and soil water moisture [32,34] are among the major factors constraining primary productivity of Mediterranean species and, thus, that may contribute significantly to the future stand composition. Acclimation to different light environments occurs at both whole-plant and leaf levels [24]; leaf acclimation being associated with morphological, anatomical and physiological changes [31]. It is suggested that plants genotipically adapted to open sunny habitats have the ability to acclimate and grow under shaded conditions [42]. In particular, seedlings growing under high irradiances are able to maintain the turgor when water is limitant by decreasing the osmotic potential, through the accumulation of osmotically active solutes or by changing the bulk leaf modulus of elasticity $[1,5$,
9]. However, Meletiou-Christou et al. [30] comparing sun and shade leaves of four evergreen sclerophylls, did not find any significant differences in the soluble sugar concentration.

Light levels in the understory of mature cork oak stands in Spain, can vary from 12 to $70 \%$ of incident radiation, depending on the structure of the stand [33]. Mortality of cork oak germinants in open areas can reach up to 90 to $100 \%$ due to the joint effect of rodents seed predation and summer drought [54]; but once the first growing season is overcome, seedlings are able to persist for 2 to 4 years and live in a suppressed state, through the dieback of the shoot during the droughty summers, followed by resprouting in the fall. The result is a recruitment of seedlings of variable age, not more than $30 \mathrm{~cm}$ high, with a deep root system, that in most cases are not able to perform adequately, as long as favourable conditions for growth do not

* Corresponding author: pardos@inia.es 
occur $[29,54]$. Thus, although mature cork oak is a shade-intolerant evergreen species, which shows a water-saver strategy under water stress $[14,34,45]$, some canopy protection during the seedling state favours its establishment and early growth.

In Mediterranean-type climates, plants are typically subjected to water stress during summer. The scarcity of rainfall during this season is generally associated with large solar radiation loads [52]. When soil water is gradually depleted, physiological mechanisms of drought tolerance, including stomatal control of water loss, osmotic adjustment [35] and development of hydraulic systems resistant to cavitation [39, 47], bring into play turgor maintenance and prevention of water loss [13, 25, $28,49,50]$. Indeed, drought tolerance in Mediterranean areas has a relevant impact on the physiological response of seedlings, even under shade conditions [53].

Because it is unlikely that tree growth is limited by deficiencies of only one resource in nature, comparative responses to multiple resources and their interactions are particularly relevant to understand adaptative strategies $[8,17,26]$. In particular, the interaction of light and water stresses may be a compromise between contradictory patterns on seedlings' physiological response. The question that arises is whether the mechanisms of drought tolerance are modified by leaf acclimation to long-term irradiance conditions [31]. According to the trade-off hypothesis mentioned by Holmgren [23] and Sack and Grubb [44], drought has a stronger impact on individuals grown in deep shade ( $<5 \%$ of full-light) than on those grown under high irradiances. Thus, lower ability for osmotic adjustment in leaves grown under increasing shade conditions within the canopy has been reported [6]. In addition, $\pi_{0}$ may decrease because of active osmolyte accumulation when seedlings of drought-tolerant species are submitted to water stress [13]. There are some studies concerned with water relations in response to light and drought and their interactions, for mediterranean species $[11,21,31,53,55]$, but little is known about cork oak. The aim of this work was to investigate leaf water relations of containerised cork oak seedlings under changing light and water conditions. The specific objectives were: (1) to determine if the occurrence of osmotic and elastic adjustment under moderate stress was similar in seedlings grown under different light environments; (2) to determine if shade can decrease seedlings' acclimation to water stress.

\section{MATERIALS AND METHODS}

\subsection{Plant material and experimental design}

A factorial experiment of two factors (light and water) of four and two levels, respectively, with treatments replicated in three blocks, was designed to test for main effects and interactions on water relation variables measured throughout two drying cycles. The four light levels varied from high to low PFD; the two water levels were well watered versus moderate stress. Twenty plants were grown under each combination and five plants per treatment combination and date were used for construction of $\mathrm{P}-\mathrm{V}$ curves.

Acorns of cork oak (Quercus suber L.) were collected from trees of the Valle del Tiétar Iberian provenance in the fall of 2000, and stored in moist plastic bags at $4{ }^{\circ} \mathrm{C}$ until germination in mid-April 2001. One germinated acorn was planted in each 3-L pot (truncated square pyramid containers, $25 \mathrm{~cm}$ height, $169 \mathrm{~cm}^{2}$ and $64 \mathrm{~cm}^{2}$, upper and lower cross-sectional area, respectively), filled with a mixture of fine sand

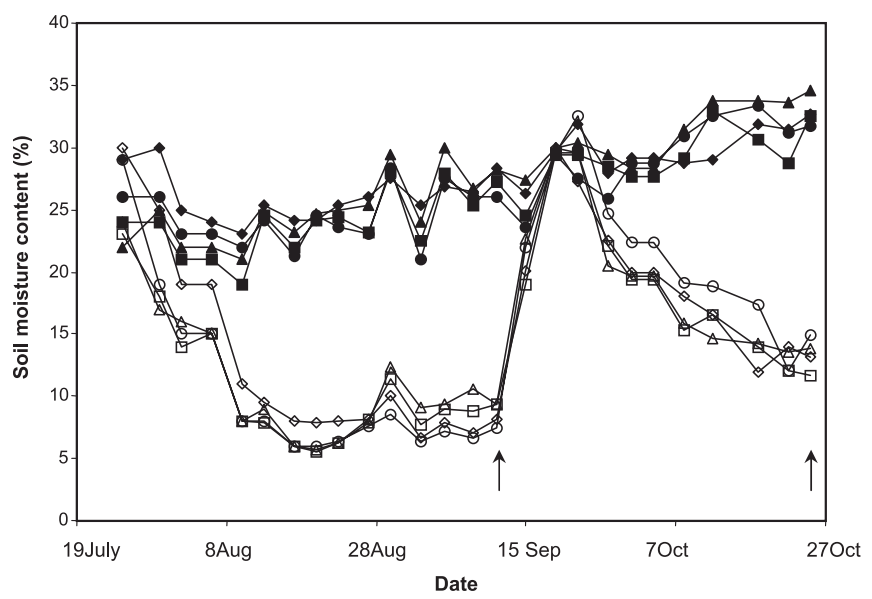

Figure 1. Variation on volumetric soil moisture content throughout the study on seedlings grown under different light environments (HL1: square; HL2: triangle; LL1: circle; LL2: diamond) and watered to field capacity (solid symbols) or submitted to two soil-drying cycles (open symbols). Volumetric soil water content in the W+ seedlings was maintained between $25 \%$ and $35 \%$, while $\mathrm{W}$ - seedlings were allowed to dry to a water content between $7 \%$ and $10 \%$. At the end of the first soil-drying cycle $\mathrm{W}$ - seedlings were watered to runoff on 20 and 23 Sept, before beginning the second soil-drying cycle. Arrows showed date of P-V curves construction. Analysis of variance in every measuring date showed no significant differences between light levels for seedlings in $\mathrm{W}-$ or $\mathrm{W}+$ treatment $(P>0.05)$.

and peat moss $(1: 3, \mathrm{v} / \mathrm{v})$. Five grams per litre of a six months controlled-release fertilizer (N:P:K, 20:10:20 + micronutrients) was added to the growing media. Seedlings were grown in the greenhouse $\left(30^{\circ} \mathrm{C}\right.$ day $/ 10^{\circ} \mathrm{C}$ night temperature, under natural photoperiod, 750 $850 \mu \mathrm{mol} \cdot \mathrm{m}^{-2} \cdot \mathrm{s}^{-1}$ of radiation intensity at midday) and kept well watered twice a week. On 27 May 2001 seedlings were placed under a transparent plastic shelter $(15 \mathrm{~m}$ long $\times 6.8 \mathrm{~m}$ wide $\times 2.3 \mathrm{~m}$ high $)$, with the sides and ends opened to facilitate circulation of air. Seedlings were randomly divided in four groups, according to the four light environments. Plants were grown under metal frames with different layers of neutral shade white cloth (Polysack Plastic Industries Ltd., Israel) to produce the four light environments. The design of the frame was optimized to avoid any effect on the temperature of the air in contact with the plants. The average photosynthetic photon flux density (PFD) under each light environment during a sunny day was: HL1: 66-70\% $\left(34.66 \mathrm{~mol} \cdot \mathrm{m}^{-2} \cdot \mathrm{day}^{-1}\right)$; HL2: 44-50\% (23.22 $\left.\mathrm{mol} \cdot \mathrm{m}^{-2} \cdot \mathrm{day}^{-1}\right)$, LL1: $13.5-16 \%\left(7.92 \mathrm{~mol} \cdot \mathrm{m}^{-2} . \mathrm{day}^{-1}\right)$ and LL2: 5-6\% $\left(2.59 \mathrm{~mol} \cdot \mathrm{m}^{-2}\right.$. day $\left.{ }^{-1}\right)$ of full sunlight.

Seedlings under each frame were randomly divided in two groups, one of which was watered to field capacity twice per week $(\mathrm{W}+)$ and the other group was subjected to a series of two soil-drying cycles of 51 and 38 days ( $\mathrm{W}-$ ), respectively, beginning on 23 July and extending to 24 October. Moderate water-stressed seedlings ( $\mathrm{W}-$ ) were watered to runoff at the end of the first drying cycle. Volumetric soil water content was monitored twice per week at $15 \mathrm{~cm}$ depth with time domain reflectometry (TDR, Trase System I, Soil Moisture Equipment Corp., USA). Volumetric soil water content in the well-watered seedlings (W+) was maintained between $25 \%$ and $35 \%$, while seedlings under moderate stress $(\mathrm{W}-)$ were allowed to dry to a water content between $7 \%$ and $10 \%$ (end of the first soil-drying cycle) (Fig. 1). The exact amount of water supplied in the $\mathrm{W}$ - treatment was a function of the volume of water lost under the lowest PFD (LL2), which had the minimum evaporative demands. By this means, a slow rate of imposition 
of the water stress conditions was assured. Analysis of variance of water content in every measuring date showed no significant differences between light levels for seedlings in the $\mathrm{W}-$ treatment $(P>0.05)$.

\subsection{Measurements}

At the end of each soil-drying cycle, five plants per each light $x$ water regime combination were harvested for determination of tissue water relation parameters. Previous to construction of pressure-volume $(\mathrm{P}-\mathrm{V})$ curves, predawn water potential $\left(\Psi_{\mathrm{pd}}\right)$ was measured in one leaf of the same seedlings, with a pressure chamber (PMS 1000, PMS Instrument Co., Corvallis, OR, USA). In addition, predawn ( $\left.\Psi_{\mathrm{pd}}\right)$ and midday water potential $\left(\Psi_{\mathrm{min}}\right)$ were measured between July and October ( $\Psi_{\text {pd }}$ and $\Psi_{\text {min }}:$ July 23 , Aug 13, Aug 27; Oct 3; $\Psi_{\text {pd }}$ : Sep 9, Oct 24) to assess the water status of the seedlings. At each measurement date, five seedlings were randomly selected from each light $\times$ water regime combination.

For construction of P-V curves, three fully expanded leaves were sealed with parafilm and the base of the petiole was placed in distilled water in a beaker after recutting under water. Leaves were allowed to rehydrate for an hour at room temperature. Special care was taken to prevent oversaturation of apoplasmic and intercellular spaces in leaves because of inmersion. Oversaturation during the first steps of dehydration causes the shift in leaf saturation deficit due to water losses without changes in measured water potential $[16,27]$. The repeat pressurization technique [22] was used to construct $P V$ curves from a series of parallel fresh weight and pressure chamber $\Psi$ measurements. After each $\Psi$ measurement, leave samples were removed from the chamber, weighed again inmediately and allowed to air dry between consecutive $\Psi$ determinations. When approximately 7-8 data points on the apparent linear portion of the PV curves were obtained, samples were placed in an oven at $70{ }^{\circ} \mathrm{C}$ for $48 \mathrm{~h}$ to obtain leaf dry weight (DW). Sample relative water content (RWC) was calculated as (fresh weight - dry weight) / (turgent weight - dry weight). Weight at turgor was derived from the relationship between fresh weight and water potential. Data points above loss of turgor were identified and turgent weight determined by linear regression $\left(r^{2}>0.98\right)$ [27].

For the derivation of PV parameters, paired observations of $\Psi$ and RWC were plotted using (1/ $/$ ) transformations [51] to identify data points to be included in simple regression analysis of the linear portion of PV curves. For the regression analysis, $1 / \Psi$ and RWC were used as the dependent and independent variables, respectively. The $\mathrm{x}-$ and $\mathrm{y}$ intercepts yielded estimates of the water content in the symplast at full turgor $\left(\mathrm{RWC}_{\mathrm{a}}\right)$ and inverse of osmotic potential at full turgor $\left(\Psi^{2} \pi_{100}\right)$. The $\mathrm{x}$ - and $\mathrm{y}$-coordinates of the first data point of the linear portion of the PV curve corresponded to relative water content at the turgorloss point $\left(\mathrm{RWC}_{0}\right)$ and inverse of osmotic potential at the turgor-loss point $\left(\Psi \pi_{0}\right)$. From the relationship between $1 / \Psi$ and RWC, the relationship between turgor pressure $(\mathrm{P})$ and RWC was calculated. Values for the bulk tissue elastic modulus $(\varepsilon)$ were calculated from this latter relationship. The bulk tissue elastic modulus is defined as the change in tissue turgor pressure for a given fractional change in symplastic content $\left(\varepsilon=\mathrm{dP} / \mathrm{dRWC}\left(\mathrm{RWC}-\mathrm{RWC}_{\mathrm{a}}\right)\right)$. Osmotic and elastic adjustments, defined as the decrease in osmotic potential at full turgor or in $\varepsilon$, respectively, in response to water deficits were calculated. Estimates of $\Psi \pi_{100}$ and $\varepsilon$ were used to characterize osmotic and elastic adjustments.

After construction of $\mathrm{P}-\mathrm{V}$ curves, five to six leaves per seedling were oven-dried at $70{ }^{\circ} \mathrm{C}$ during $48 \mathrm{~h}$ and ground in a mill fitted with a $0.7 \mathrm{~mm}$ screen. Samples were analysed for soluble sugar concentration (mmol). Approximately $0.1 \mathrm{~g}$ of ground tissue was extracted three times in boiling $80 \%(\mathrm{v} / \mathrm{v})$ ethanol, centrifuged and the supernatants pooled. Soluble sugars were quantified spectrophotometrically following reaction with anthrone [46].

\subsection{Statistical analysis}

A factorial arrangement of sample date, water regime and light was employed in a completely randomized design. Analysis of variance was conducted using the SAS GLM procedure. Comparison of mean treatment differences was done by Tukey test. As sample date was not significant, data from the two harvests were pooled, and a two-way fixed effects general linear model with the treatments of water regime and light as the main effects was used. The relationship between variables was assessed using the Pearson $(r)$ coefficient, and considering the individual values of all seedlings.

Linear regressions of osmotic potential at full turgor $\left(\Psi \pi_{100}, \mathrm{MPa}\right)$ and at the turgor-loss point $\left(\Psi \pi_{0}, \mathrm{MPa}\right)$ with predawn water potential $\left(\Psi_{\mathrm{pd}}\right)$ were made. In a first step, functions were fitted to data from each light treatment independently (1). In a second step, a unique fit was made for all the data (2). In a third step, data from the four light treatments were grouped in two groups, high light $(\mathrm{HL}=\mathrm{HL} 1+\mathrm{HL} 2)$ and low light $(L L=L L 1+$ LL2 $)$, and two new functions were fitted to them (3). Once all regressions were proved significant, we determined whether significant differences exist among light treatments by a $F$-test for detecting simultaneous homogeneity among parameters of the regressions. The method requires the fitting of a full and a reduced model. The full model fitted a function for each light treatment. When comparing (1) and (2), the reduced model made a unique fit to all four treatments in the data set. When comparing (1) and (3), the reduced model fitting was done by calculating a different set of parameters for HL and LL groups

The F-test uses the following statistic:

$$
F=\frac{\frac{S S_{r}-S S_{f}}{d f_{r}-d f_{f}}}{\frac{S S_{f}}{d f_{f}}}
$$

where $S S_{f}=$ sum of squares error for full model; $S S_{r}=$ sum of squares error for reduced model; $d f_{f}=$ degrees of freedom for full model; $d f_{r}=$ degrees of freedom for reduced model. The statistical decision rule at the given significance $\alpha$ level is:

If $F>F_{\text {Fisher-Snedecor }}\left(1-\alpha ; d f r-d f_{f} ; d f_{f}\right)$, the separate models are required.

If $F<F_{\text {Fisher-Snedecor }}\left(1-\alpha ; d f r-d f_{f} ; d f_{f}\right)$, the reduced model is appropriate.

\section{RESULTS}

Significant differences between water regimes were found for $\Psi_{\mathrm{pd}}$ and $\Psi_{\min }$ in all measurement dates $(P<0.001)$, except at the beginning of the two soil-drying cycles (July 23 and Oct 3), when soil water moisture was high and similar in all seedlings (Fig. 2). Well-watered seedlings had higher values of $\Psi_{\text {pd }}$ and $\Psi_{\text {min }}$ compared to seedlings submitted to moderate water stress (Fig. 2). The lowest $\Psi_{\text {pd }}$ values in the moderate water stressed seedlings were shown at the end of each soildrying cycle. Predawn water potential $\left(\Psi_{\mathrm{pd}}\right)$ and midday water potential $\left(\Psi_{\min }\right)$ were not affected by light $(P>0.05)$; this result elucidated a similar imposition of the water regime, independently of the irradiance under which seedlings were grown (Fig. 2).

Soluble sugar concentration expressed on a leaf area basis was significantly higher under high light environments (HL1 and HL2), for both water regimes $(P<0.001$, Fig. 3$)$. The concentration under the HL1 treatment was between 1.8 (for $\mathrm{W}+$ ) and 2.8-fold (for $\mathrm{W}-$ ) the value under the LL2 treatment. 


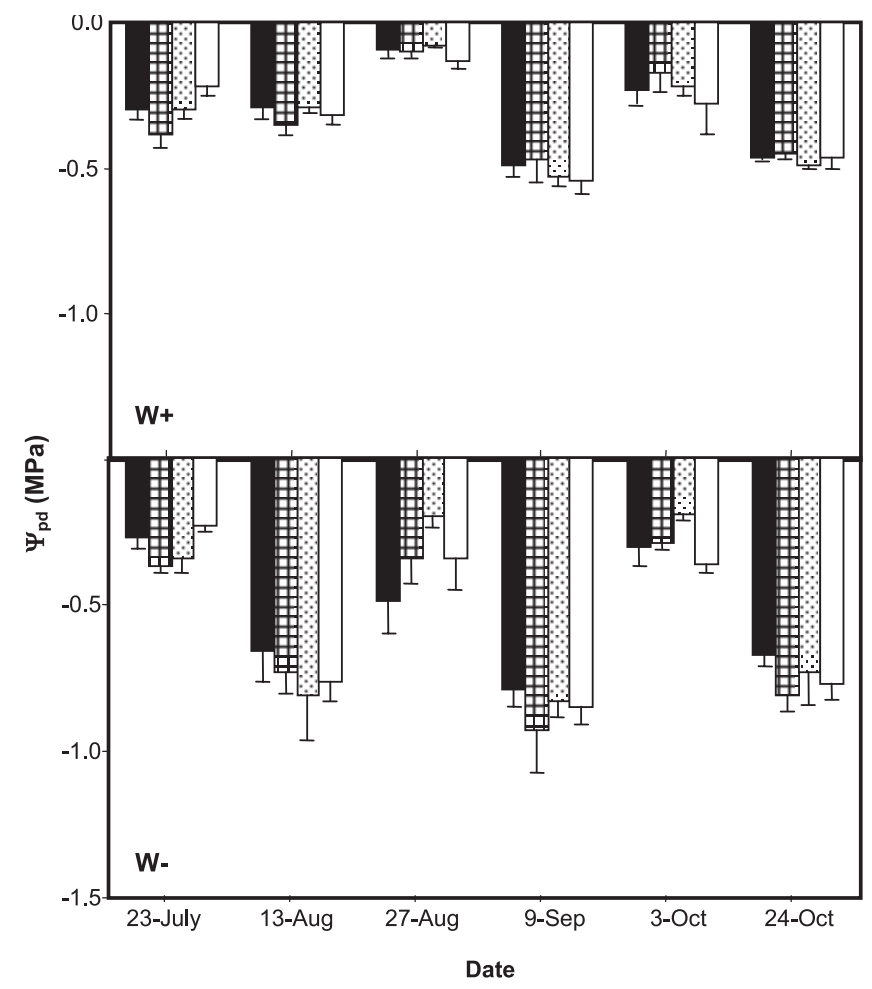

(a)

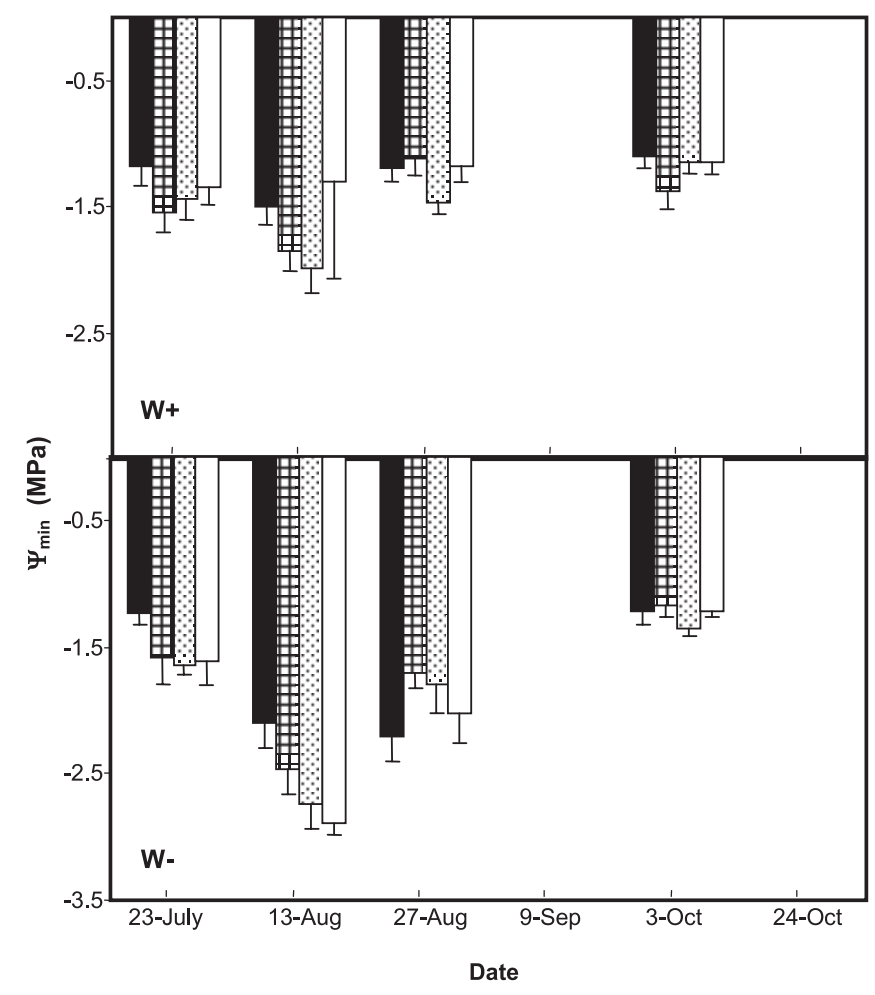

(b)

Figure 2. Time course of (a) predawn $\left(\Psi_{\mathrm{pd}}, \mathrm{MPa}\right)$ and (b) midday leaf water potential ( $\Psi_{\min }$, MPa) on cork oak seedlings watered to field capacity $(\mathrm{W}+)$ or submitted to a moderate water stress (W-) and grown under different light environments [HL1 (66-70\%): $\mathbf{\square}$; HL2 (44-50\%): 田; LL1 (13.5-16\%): 甬; LL2 (5-6\%): $\square$ ].

Both the osmotic potential at full turgor $\left(\Psi \pi_{100}\right)$ and at the turgor-loss point $\left(\Psi \pi_{0}\right)$ were significantly affected by water and light treatments, although their variation was mostly explained by water availability (Tab. I). Thus, moderate water-stressed seedlings showed significant lower $\Psi \pi_{100}$ and $\Psi \pi_{0}$ under the four light treatments (Fig. 4). Seedlings grown under LL1 and LL2 light levels showed higher $\Psi \pi_{100}$ and $\Psi \pi_{0}$, than seedlings grown under HL1 and HL2. Bulk modulus of elasticity at maximum turgor $\left(\varepsilon_{\max }\right)$ was affected by water regime, but only under the two highest light environments (HL1 and HL2) (Fig. 4). High cell-wall rigidity was related to high $\mathrm{RWC}_{0}$ and low $\mathrm{RWC}_{\mathrm{a}}, \Psi_{\mathrm{pd}}, \Psi \pi_{100}$ and $\Psi \pi_{0}$ (Tab. II). The rest of parameters derived from the $\mathrm{P}-\mathrm{V}$ curves (relative water content at the turgor loss point, $\mathrm{RWC}_{0}$, and relative symplastic water content, $\mathrm{RWC}_{\mathrm{S}}$ ) showed no evident trend related to treatment. Estimates of $\Psi \pi_{100}$ are used to characterize osmotic adjustment, and decreases of $0.48,0.46,0.28$ and $0.28 \mathrm{MPa}$ were recorded for the HL1, HL2, LL1 and LL2, respectively.

At a significant level $\alpha=5 \%$, when comparing (1) and (2), we reject the null hypothesis of parameters homogeneity, which means that separate models were required for each of the four light treatments. When comparing (1) and (3), we cannot reject the null hypothesis, accepting that the reduced model was appropriate for the light treatment. Thus, a different model was fitted for the high light group (HL= HL1 + HL2) and the low light group $(\mathrm{LL}=\mathrm{LL} 1+\mathrm{LL} 2)$. Values of F statistic and results of fitting the functions for the HL and LL groups are shown in Table III. For both light groups, $\Psi \pi_{100}$ and $\Psi \pi_{0}$ values in seedlings submitted to a moderate water stress were significantly lower than values in the well irrigated seedlings (Fig. 5). Low $\Psi_{\text {pd }}$ induced low $\Psi \pi_{100}$ and $\Psi \pi_{0}$ values, irrespective of light environment.

\section{DISCUSSION}

Tissue water relation parameters in cork oak seedlings changed in response to water availability and light environment. Water potential ( $\Psi_{\mathrm{pd}}$ and $\left.\Psi_{\min }\right)$ was higher in well-irrigated seedlings, for all light levels, suggesting a generally small effect of light on water potential, as previously reported by Rhizopoulou et al. [42] in four Mediterranean evergreen sclerophylls. At the end of the second soil-drying cycle, there was a significant trend for higher $\Psi_{\text {pd }}$ values in well-irrigated seedlings grown under the high light environments $(-0.45 \mathrm{MPa}$ in HL1 and HL2 vs. $-0.49 \mathrm{MPa}$ in LL1 and LL2, $P=0.0129$, Fig. 2). Similarly, Abrams [1] and Kloeppel et al. [25] found higher $\Psi_{\mathrm{pd}}$ under sunny conditions, although it is not a general pattern $[5,17,41,53]$.

The decrease in osmotic potential $\left(\Psi \pi_{100}\right.$ and $\left.\Psi \pi_{0}\right)$ as water availability decreased and PFD increased, allows seedlings to maintain a water potential gradient from the soil to the plant and to facilitate water uptake. Although no interaction was 


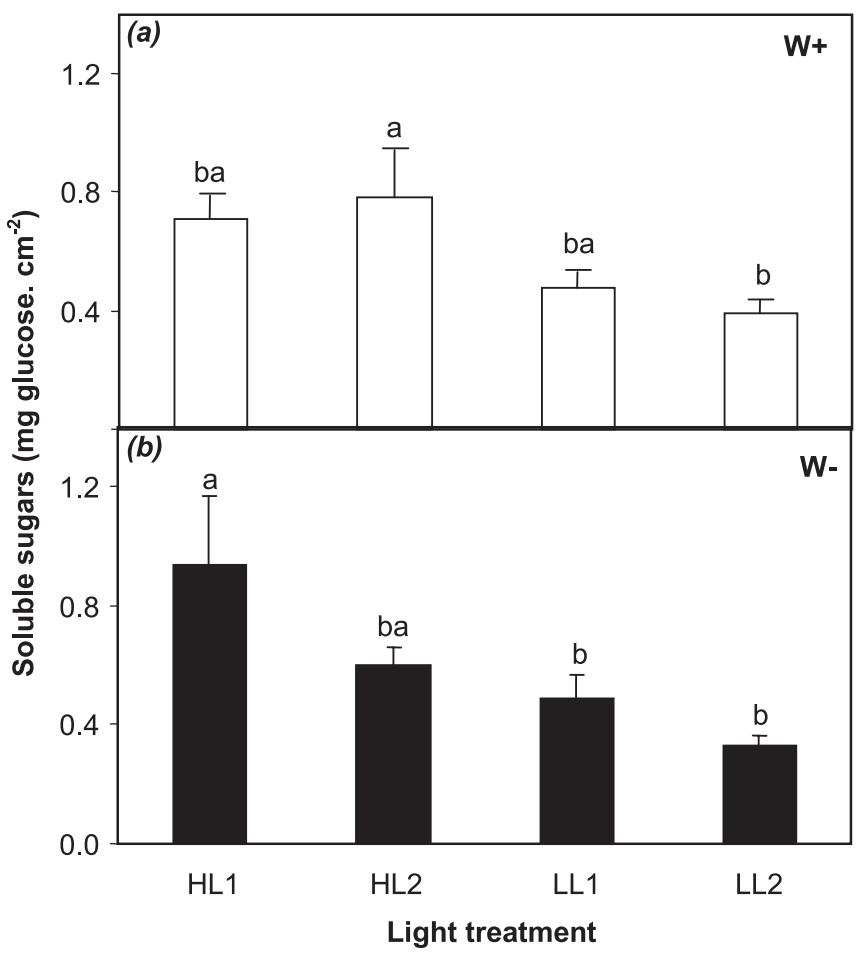

Figure 3. Sugar soluble concentration $\left(\mathrm{mg}\right.$ glucose $\left.\cdot \mathrm{cm}^{-2}\right)$ in leaves of cork oak seedlings grown under four light environments (HL1: 6670\%; HL2: 44-50\% , LL1: 13.5-16\% and LL2: 5-6\% of full sunlight) and watered to field capacity $(\mathrm{W}+)(\mathbf{a})$, or subjected to a moderate water stress $\left(\mathrm{W}_{-}\right)(\mathbf{b})$. Means separation between light environments by $t$-test, $P<0.05$.

Table I. Analysis of variance for pressure-volume curve parameters. Factors are light (d.f. 3), water (d.f. 1), and their interaction (d.f. 3).

\begin{tabular}{lcrr}
\hline Variable & Factor & \multicolumn{1}{c}{$F$} & \multicolumn{1}{c}{$P$} \\
\hline$\Psi \pi_{0}$ & Light & 9.34 & $<0.0001$ \\
& Water & 43.09 & $<0.0001$ \\
& Light $\times$ Water & 0.16 & 0.9246 \\
$\Psi \pi_{100}$ & Light & 6.32 & 0.0008 \\
& Water & 35.83 & $<0.0001$ \\
& Light $\times$ Water & 0.67 & 0.5750 \\
$\Psi_{\text {pd }}$ & Light & 0.48 & 0.6964 \\
& Water & 45.00 & $<0.0001$ \\
& Light $\times$ Water & 0.54 & 0.6534 \\
$\Psi_{\text {pd }}-\Psi \pi_{0}$ & Light & 6.26 & 0.0008 \\
& Water & 3.72 & 0.0196 \\
\multirow{2}{*}{$\mathrm{RWC} C_{0}$} & Light $\times$ Water & 0.23 & 0.8773 \\
& Light & 0.30 & 0.8234 \\
\multirow{2}{*}{$\mathrm{RWCa}$} & Water & 0.25 & 0.6177 \\
& Light $\times$ Water & 0.79 & 0.5039 \\
& Light & 1.36 & 0.2621 \\
$\varepsilon_{\text {max }}$ & Water & 0.03 & 0.8739 \\
& Light $\times$ Water & 0.10 & 0.9624 \\
& Light & 0.74 & 0.5307 \\
& Water & 3.70 & 0.0500 \\
& Light $\times$ Water & 2.25 & 0.0909 \\
\hline
\end{tabular}
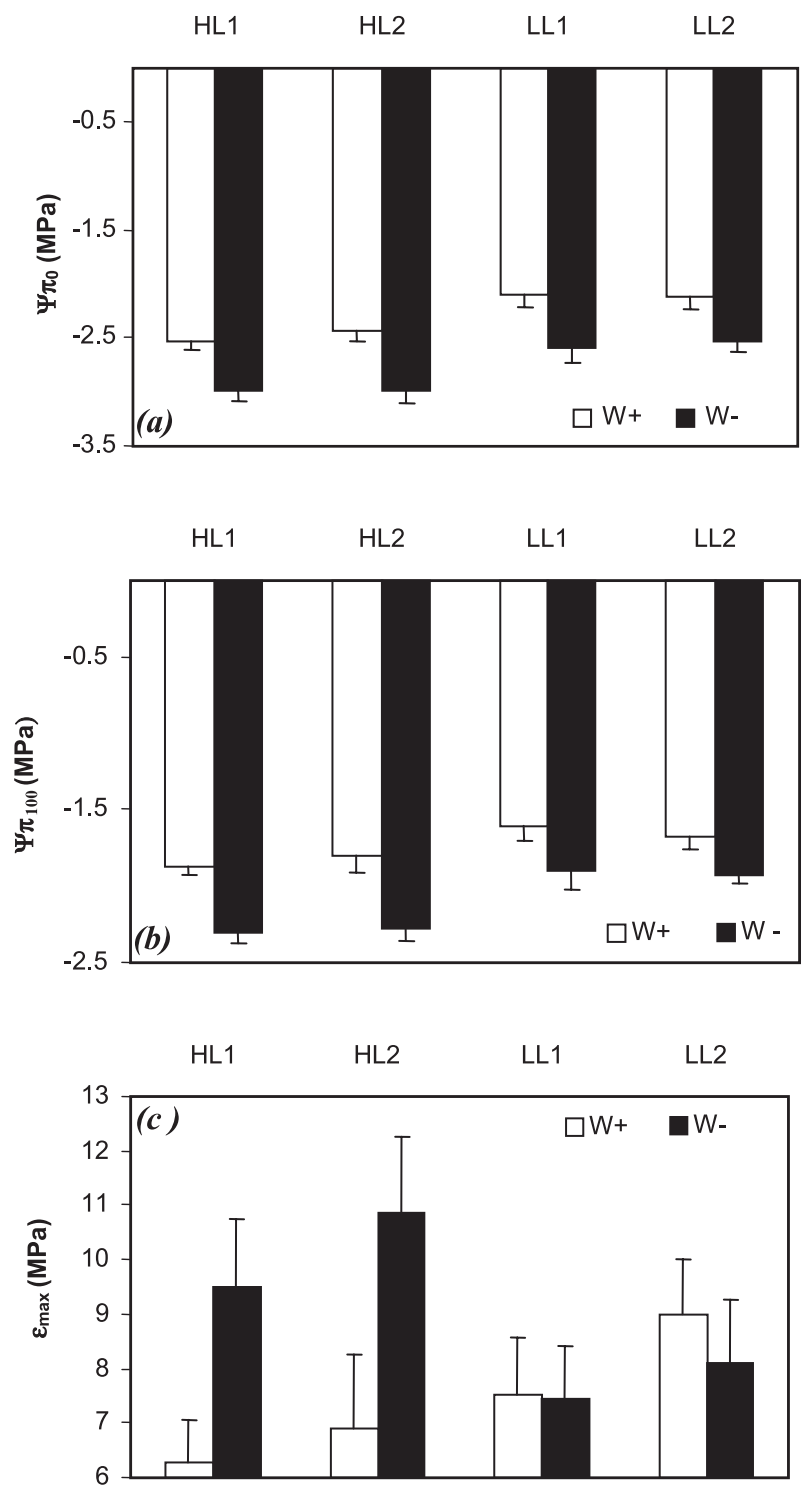

Figure 4. Osmotic potential at full $\left(\Psi \pi_{100}, \mathrm{MPa}\right)(\mathbf{a})$ and at turgorloss point $\left(\Psi \pi_{0}, \mathrm{MPa}\right)(\mathbf{b})$, and bulk modulus of elasticity $\left(\varepsilon_{\max }, \mathrm{MPa}\right)$ (c) in cork oak seedlings watered to field capacity, W+ (white symbols) or submitted to two soil-drying cycles, W- (black symbols), under different light environments (HL1: 66-70\%, HL2: 44-50\%, LL1: $13.5-16 \%$ and LL2: 5-6\% of full sunlight).

shown between light and water availability, $\Psi \pi_{0}$ was lower under high light (HL1 and HL2) for both water regimes. In addition, $\Psi \pi_{100}$ was lower under high light (HL1 and HL2), but only for moderate water-stressed seedlings. As suggested by Aranda et al. [7] the additive effect of high irradiance and low water availability can start mechanisms of drought tolerance such as a decrease on $\Psi \pi_{0}$. Active accumulation of solutes decreases $\Psi \pi_{0}$, acting to sustain a gradient in $\Psi$ between plant protoplasm and the soil solution [8]. In this way, osmotic adjustment may facilitate water uptake, turgor potential maintenance, and tissue survival at the low tissue $\Psi$ that results from water stress. For both water treatments, seedlings grown at high irradiances 
Table II. Correlation values (Pearson's $r$ ) of different water relation parameters considering all seedlings $(n=80)$. Probability values are shown in parenthesis (values in bold: $P<0.05)$, ns: non-significant. Abbreviations: predawn leaf water potential $\left(\Psi_{\text {pd }}\right.$, MPa), leaf water potential al the turgor-loss point $\left(\Psi \pi_{0}, \mathrm{MPa}\right)$, osmotic potential at full turgor $\left(\Psi \pi_{100}, \mathrm{MPa}\right)$, relative water content at turgor-loss point $\left(\mathrm{RWC} \mathrm{C}_{0}\right)$, relative apoplastic water content $\left(\mathrm{RWC}_{\mathrm{a}}\right)$, turgent to dry weight ratio (TW/DW), bulk modulus of elasticity at maximum turgor $\left(\varepsilon_{\mathrm{max}}\right.$, MPa).

\begin{tabular}{lccccc}
\hline & $\Psi_{\mathrm{pd}}$ & $\Psi \pi_{0}$ & $\Psi \pi_{100}$ & $\mathrm{RWC}_{0}$ & $\mathrm{RWC}_{\mathrm{a}}$ \\
\hline$\Psi \pi_{0}$ & $0.52(<\mathbf{0 . 0 0 0 1})$ & & & & \\
$\Psi \pi_{100}$ & $0.51(<\mathbf{0 . 0 0 0 1})$ & $0.92(<\mathbf{0 . 0 0 0 1})$ & & & \\
$\mathrm{RWC}_{0}$ & $\mathrm{~ns}$ & $0.29(\mathbf{0 . 0 1 1 4})$ & $\mathrm{ns}$ & & \\
$\mathrm{RWC}_{\mathrm{a}}$ & $\mathrm{ns}$ & $0.22(0.0570)$ & $0.40(\mathbf{0 . 0 0 0 3})$ & $0.59(<\mathbf{0 . 0 0 0 1})$ & \\
$\varepsilon_{\max }$ & $-0.37(\mathbf{0 . 0 0 1 1})$ & $-0.30(\mathbf{0 . 0 0 9 0})$ & $-0.56(<\mathbf{0 . 0 0 0 1})$ & $0.27(\mathbf{0 . 0 1 9 5})$ & $-0.39(\mathbf{0 . 0 0 0 7})$ \\
\hline
\end{tabular}

Table III. Linear regression analysis, using the equations $\Psi \pi_{0}=\mathrm{a}+$ b. $\Psi_{\text {pd }}$ or $\Psi \pi_{100}=\mathrm{a}^{\prime}+\mathrm{b}^{\prime} . \Psi_{\mathrm{pd}} . F$ statistic and summary results for the fit of the functions are shown. (1) functions are fitted to data from each light treatment independently; (2) a unique fit is made for all the data; (3) data from the four light treatments are grouped in high light $(\mathrm{HL}=\mathrm{HL} 1+\mathrm{HL} 2)$ and low light (LL = LL1 + LL2) environments, and two new functions are fitted to them.

\begin{tabular}{|c|c|c|c|c|c|c|}
\hline \multirow[t]{2}{*}{ Light groups } & \multirow[t]{2}{*}{$n$} & \multicolumn{2}{|c|}{$\Psi \pi_{0}$ vs. $\Psi_{\mathrm{pd}}$} & \multicolumn{3}{|c|}{$\Psi \pi_{100}$ vs. $\Psi_{\mathrm{pd}}$} \\
\hline & & $F$ & $P>F$ & & & $P>F$ \\
\hline (1) vs. (2) & 75 & 5.823 & $6.300 \mathrm{E}-5$ & & & 0.0016 \\
\hline \multirow[t]{4}{*}{ (1) vs. (3) } & 75 & 0.500 & 0.736 & & & 0.655 \\
\hline & \multicolumn{3}{|c|}{$\Psi \pi_{0}$ vs. $\Psi_{\mathrm{pd}}$} & \multicolumn{3}{|c|}{$\Psi \pi_{100}$ vs. $\Psi_{\mathrm{pd}}$} \\
\hline & \multicolumn{2}{|c|}{ Parameter estimates } & $r^{2}$ & \multicolumn{2}{|c|}{ Parameter estimates } & $r^{2}$ \\
\hline & $\mathrm{a}$ & $\mathrm{b}$ & & $\mathrm{a}^{\prime}$ & $b^{\prime}$ & \\
\hline HL & 1.09 & -2.07 & 0.40 & 0.94 & -1.48 & 0.37 \\
\hline LL & 1.33 & -1.48 & 0.35 & 0.92 & -1.19 & 0.28 \\
\hline
\end{tabular}

showed a higher soluble sugar concentration than seedlings grown under low irradiances. Similar results have been reported by Niinemets [36] in three temperate woody species and by Johnson et al. [24] in Fagus sylvatica, but contrast to those presented by Meletiou-Christou et al. [30] in four Mediterranean evergreen sclerophylls, which showed no substantial differences on soluble sugars when comparing sun and shade leaves. Changes on water availability through the growing season did not affect either soluble sugar concentration in twoyear-old cork oak seedlings grown outdoors in Portugal, although mean values are higher than ours (between 1.0 and $1.7 \mathrm{mg}$ glucose $\cdot \mathrm{cm}^{-2}$ ), probably related to seedling age [12]. The higher soluble sugar concentrations in seedlings grown under higher irradiances provoked a decrease of the osmotic potential at full turgor $\left(\Psi \pi_{100}\right)$ and are at least partly responsible for osmotic adjustment [31].

As the response to light environment was the same under both water levels, with the highest values under the high light levels (HL1 and HL2) and the lowest under the low light levels (LL1 and LL2), seedlings could be arranged in two groups according to their response to the light environment: low light level (LL $=$ LL1 + LL2 $<16 \%$ of full sun light) and high light level $(\mathrm{HL}=\mathrm{HL} 1+\mathrm{HL} 2>40 \%$ of full sun light $)$. Similar groups were defined when regressions between $\Psi \pi_{100}$ vs. $\Psi_{\text {pd }}$ and $\Psi \pi_{0}$
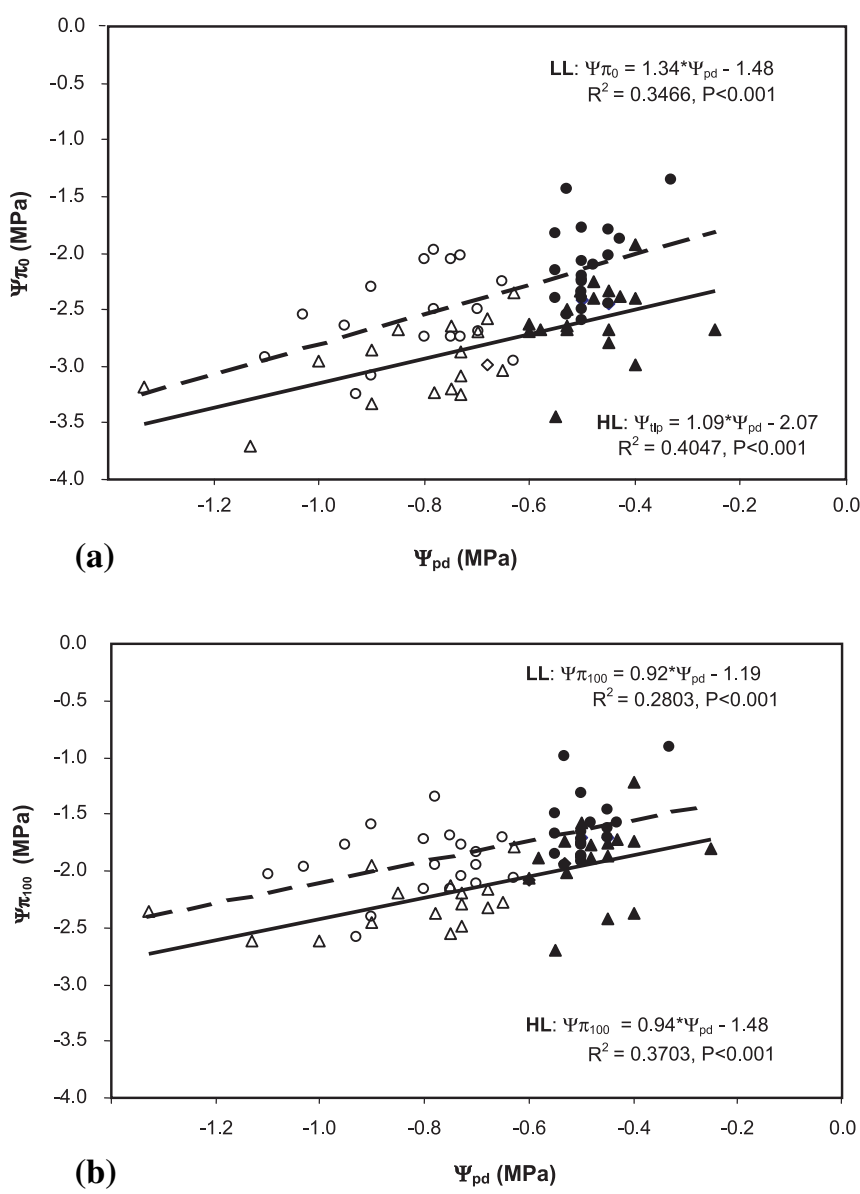

Figure 5. (a) Osmotic potential at turgor-loss point $\left(\Psi \pi_{0}\right)$ and (b) at full turgor $\left(\Psi \pi_{100}\right)$ plotted against predawn water potential $\left(\Psi_{\mathrm{pd}}\right)$. Data are derived from seedlings watered to field capacity, $\mathrm{W}+$ (solid symbols) or subjected to a moderate water stress, W-(open symbols), and grown under high light, HL (triangles) or low light conditions, LL (circles). Also shown are fitted curves for pooled data of seedlings grown under high light (-) or low light conditions (-----).

vs. $\Psi_{\text {pd }}$ were made (Fig. 5). Leaves grown under high light typically developed lower osmotic potential relative to shaded leaves $[4,8]$. The lower $\Psi \pi_{100}$ and $\Psi \pi_{0}$ irrespective of $\Psi_{\text {pd }}$ as irradiance increased has been related to lower daily leaf water potential, due to a more droughty environment [37]. Although the relationship between $\Psi \pi_{100}$ vs. $\Psi_{\text {pd }}$ with high coefficients 
of determination $\left(r^{2}>0.7\right)$ has been reported [3, 19], the lower coefficients in our study $\left(r^{2}>0.28\right)$ can result from the moderate water stress applied.

In oak species, drought commonly results in decreases in $\Psi \pi_{100}$ of about $0.6 \mathrm{MPa}$ or less $[2,3,6,13,14]$. Decreases in osmotic potential near to $0.5 \mathrm{MPa}$ under moderate drought conditions and differences in osmotic adjustment between seedlings grown under low light (LL1 and LL2) and high light (HL1 and HL2) environments of $40 \%$ demonstrated an osmotic adjustment capacity in accordance to water conditions in our study. In any case, and under both light environments, cork oak readily displayed osmotic adjustment with little change in $\Psi_{\mathrm{pd}}$, similarly to results reported in chestnut oak in an upland oak forest during a dry year [49]. Moreover, our results suggested a more limited osmotic adjustment under low light conditions (0.28 MPa) than under high light conditions (0.47 MPa), as reported by Augé et al. [8] with Rosa seedlings. Osmotic adjustment in seedlings grown under the high light environment (HL1) was also accompanied by an elastic adjustment of 3.6 MPa. The increase in osmotic adjustment capacity with light went in parallel with an increase in photosynthetic capacity (data not shown). Previous studies demonstrated the higher ability to osmotic adjustment in plants growing under high light environments $[15,31,40]$. The values of osmotic adjustment for seedlings grown under low light conditions are similar to those obtained in xeric North American oak species [3]. Values of osmotic adjustment under high light conditions are similar to those reported by Collet and Guehl [13] on sessile oak after subjecting seedlings to a slow rate of water deficit increase.

The decrease in osmotic potential at turgor loss point and at full turgor in moderate stressed seedlings was accompanied by an increase in $\varepsilon_{\text {max }}$. This is a characteristic of plants adapted to tolerate water stress $[20,43]$. This increase in $\varepsilon_{\max }$ will result in a more rapid loss of turgor for a given loss in tissue water content and hence may appear to be a disadvantage during drought [17]. However, an increase in tissue rigidity may confer physiological and ecological advantages [8]. A lower cell wall elasticity would allow leaf water potential to drop rapidly and substantially as soon as the leaves began to loose water [34, 38 ] and a rapid recovery after a decrease in soil water content, which is shown as an efficient mechanism to overcome water stress [14]. It has been suggested that a higher $\varepsilon_{\max }$ value increases water absorption in a drying soil by increasing the soil-plant water potential gradient [18]; although both lower and higher elasticity have been suggested as promoting turgor maintenance.

Results of this study suggest the development of different physiological mechanisms to withstand environmental conditions in sun and shade-grown seedlings. Osmotic and elastic adjustments are found to help cork oak seedlings to maintain turgor during moderate water stress and under high light environment ( $>40 \%$ of full sun). In contrast, in seedlings grown under moderate water stress and low light environment $(<16 \%$ of full sun), their main strategy in coping with stress was osmotic adjustment; but its lower ability for such adjustment suggests a lower efficiency in developing physiological mechanisms for drought tolerance, under low light conditions.

\section{REFERENCES}

[1] Abrams M.D., Physiological plasticity in water relations and leaf structure of understory versus open-grown Cercis canadiensis L. in northeast Kansas, Can. J. For. Res. 16 (1986) 1170-1174.

[2] Abrams M.D., Comparative water relations of three successional hardwood species in central Wisconsin, Tree Physiol. 4 (1988) 263-273.

[3] Abrams M.D., Adaptations and responses to drought in Quercus species of North America, Tree Physiol. 7 (1990) 227-238.

[4] Abrams M.D., Kloeppel B.D., Kubiske M.E., Ecophysiological and morphological responses to shade and drought in two contrasting ecotypes of Prunus serotina, Tree Physiol. 10 (1992) 343-355.

[5] Aranda I., Gil L., Pardos J.A., Effects of thinning in a Pinus sylvestris L. stand on foliar water relations of Fagus sylvatica L. seedlings planted within the pinewood, Trees 15 (2001) 358-364.

[6] Aranda I., Gil L., Pardos J.A., Osmotic adjustment in two temperate oak species [Quercus pyrenaica Willd and Quercus petraea (Matt.) Liebl] of the Iberian Peninsula in response to drought, Investigación Agraria: Sistemas y Recursos Forestales 13 (2004) 339-345.

[7] Aranda I., Castro L., Pardos M., Gil L., Pardos J.A., Effects of the interaction between drought and shading on water relations, gas exchange and morphological traits in cork oak (Quercus suber L.) seedlings, For. Ecol. Manage. 210 (2005) 117-129.

[8] Augé R.M., Stodola A.J.W., Pennell B.D., Osmotic and turgor adjustment in Rosa foliage drought-stressed under varying irradiance, J. Amer. Soc. Hort. Sci. 115 (1990) 661-667.

[9] Blake T.J., Bevilacqua E., Zwiazek J.J., Effects of repeated stress on turgor pressure and cell elasticity changes in black spruce seedlings, Can. J. For. Res. 21 (1991) 1329-1333.

[10] Castell C., Terradas J., Tenhunen J.D., Water relations, gas exchange, and growth of resprouts and mature plant shoots of $\mathrm{Arbu}$ tus unedo L. and Quercus ilex L, Oecologia 98 (1994) 201-211.

[11] Cavender-Bares J., Bazzaz F.A., Changes in drought response strategies with ontogeny in Quercus rubra: implications for scaling from seedling to mature trees, Oecologia 124 (2000) 8-18.

[12] Cerasoli S., Scartazza A., Brugnoli E., Chaves M.M., Pereira J.S., Effects of partial defoliation on carbon and nitrogen partitioning and photosynthetic carbon uptake by two-year-old cork oak ( $Q u e r$ cus suber) saplings, Tree Physiol. 24 (2004) 83-90.

[13] Collet C., Guehl J.M., Osmotic adjustment in sessile oak seedlings in response to drought, Ann. Sci. For. 54 (1997) 389-394.

[14] Corcuera L., Camarero J.J., Gil-Pelegrín E., Functional groups in Quercus species derived from the analysis of pressure-volume curves, Trees 16 (2002) 465-472.

[15] Delpérée C., Kinet J.M., Lutts S., Low irradiance modifies the effect of water stress on survival and growth-related parameters during the early developmental stages of buckwheat (Fagopyrum esculetum), Physiol. Plant. 119 (2003) 211-220.

[16] Dreyer E., Bousquet F., Ducrey M., Use of pressure volume curves in water relation analysis on woody shoots: influence of rehydration and comparison of four European oak species, Ann. Sci. For. 47 (1990) 285-297.

[17] Ellsworth D.S., Reich P.B., Water relations and gas exchange of Acer saccharum seedlings in contrasting natural light and water regimes, Tree Physiol. 10 (1992) 1-20.

[18] Fan S., Blake T.J., Blumwald E., The relative contribution of elastic and osmotic adjustments to turgor maintenance of woody species, Physiol. Plant. 90 (1994) 408-413. 
[19] Gebre G.M., Tschaplinski T.J., Shirshac T.L., Water relations of several hardwood species in response to throughfall manipulation in an upland oak forest during a wet year, Tree Physiol. 18 (1998) 299-305.

[20] Groom P.K., Lamont B.B., Xerophytic implications of increased sclerophylly: interactions with water and light in Hakea psilorrhyncha seedlings, New Phytol. 136 (1997) 231-237.

[21] Van Hees A.F.M., Growth and morphology of pedunculate oak (Quercus robur L.) and beech (Fagus sylvatica L.) seedlings in relation to shading and drought, Ann. Sci. For. 54 (1997) 9-18.

[22] Hinckley T.M., Duhme F., Hinckley A.R., Richter H., Water relations of drought hardy shrubs: osmotic potential and stomatal reactivity, Plant Cell Environ. 3 (1980) 131-140.

[23] Holmgren M., Combined effects of shade and drought on tulip poplar seedlings: trade-off in tolerance or facilitation? Oikos 90 (2000) 67-78.

[24] Johnson J.D., Tognetti R., Michelozzi M., Pinzauto S., Minota G., Borghetti M., Ecophysiological responses of Fagus sylvatica seedlings to changing light conditions. II. The interaction of light environment and soil fertility on seedling physiology, Physiol. Plant. 101 (1997) 124-134.

[25] Kloeppel B.D., Kubiske M.E., Abrams M.D., Seasonal tissue water relations of four successional pennsylvania barrens species in open and understory environments, Int. J. Plant Sci. 155 (1994) 73-79.

[26] Kolb T.E., Steiner K.C., McCormick L.H., Bowersox T.W., Growth responses of northern red-oak and yellow-poplar seedlings to light, soil moisture and nutrients in relation to ecological strategy, For. Ecol. Manage. 38 (1990) 65-78.

[27] Kubiske M.E., Abrams M.D., Pressure-volume relationships in non-rehydrated tissue at various water deficits, Plant, Cell Environ. 13 (1990) 995-1000.

[28] Kwon K.W., Pallardy S.G., Temporal changes in tissue water relations of seedlings of Quercus acutissima, Q. alba, and Q. stellata subjected to chronic water stress, Can. J. For. Res. 19 (1989) 622 626.

[29] Larsen D.R., Johnson P.S., Linking the ecology of natural oak regeneration to silviculture, For. Ecol. Manage. 106 (1998) 1-7.

[30] Meletiou-Christou M.S., Rhizopoulou S., Diamantoglou S., Seasonal changes of carbohydrates, lipids and nitrogen in sun and shade leaves from four Mediterranean evergreen sclerophylls, Environ. Exp. Bot. 34 (1994) 129-140.

[31] Mendes M.M., Gazarini L.C., Rodrigues M.L., Acclimation of Myrtus communis to contrasting Mediterranean light environmentseffects on structure and chemical composition of foliage and plant water relations, Environ. Exp. Bot. 45 (2001) 165-178.

[32] Méthy M., Damesin C., Rambal S., Drought and photosystem II activity in two Mediterranean oaks, Ann. Sci. For. 53 (1996) 255262.

[33] Montero G., Cañellas I., Selvicultura de los alcornocales en España, Silva Lusitana 11 (2003) 1-19.

[34] Nardini A., Lo Gullo M.A., Salleo S., Competitive strategies for water availability in two Mediterranean Quercus species, Plant, Cell Environ. 22 (1999) 109-116.

[35] Nguyen-Queyrens A., Costa P., Loustau D., Plomion C., Osmotic adjustment in Pinus pinaster cuttings in response to a soil drying cycle, Ann. For. Sci. 59 (2002) 795-799.

[36] Niinemets Ü., Role of foliar nitrogen in light harvesting and shadetolerance of four temperate deciduous woody species, Funct. Ecol. 11 (1997) 518-531.
[37] Niinemets Ü., Components of leaf dry mass per area- thickness and density- alter leaf photosynthetic capacity in reverse directions in woody plants, New Phytol. 144 (1999) 35-47.

[38] Osonubi O., Davis W.J., Root growth and water relations of oak and birch seedlings. Oecologia 51 (1981) 343-350.

[39] Perks M.P., Irvine J., Grace J., Xylem acoustic signals from mature Pinus sylvestris during an extended drought, Ann. For. Sci. 61 (2004) $1-8$.

[40] Pothier D., Margolis H.A., Changes in the water relations of balsam fir and white birch saplings after thinning, Tree Physiol. 6 (1990) 371-380.

[41] Reich P.B., Hinckley T.M., Water relations, soil fertility, and plant nutrient content of a pygmy oak ecosystem, Ecology 61 (1980) $400-416$.

[42] Rhizopoulou S., Meletiou-Christou M.S., Diamantoglou S., Water relations for sun and shade leaves of four Mediterranean evergreen sclerophylls, J. Exp. Bot. 42 (1991) 627-635.

[43] Robichaux R.H., Variation in the tissue water relations of two sympatric Hawaiian Dubautia species and their natural hybrid, Oecologia 65 (1984) 75-81.

[44] Sack L., Grubb P.J., The combined impacts of deep shape and drought on the growth and biomass allocation of shade-tolerant woody seedlings, Oecologia 131 (2002) 175-185.

[45] Salleo S., LoGullo M.A., Sclerophylly and plant water relations in three mediterranean Quercus species, Ann. Bot. 65 (1990) 259 270.

[46] Spiro R.G., Analysis of sugars found in glycoproteins, in: Neufeld E.F., Ginsburg V. (Eds.), Methods in Enzymology VIII, Complex Carbohydrates, Academic Press, New York, 1966, pp. 3-26.

[47] Tissier J., Lambs L., Peltier J.P., Marigo G., Relationships between hydraulic traits and habitat preference for six Acer species occurring in the French Alps, Ann. For. Sci. 61 (2004) 81-86.

[48] Tognetti R., Michelozzi M., Borghetti M., Response to light of shade-grown beech seedlings subjected to different watering regimes, Tree Physiol. 14 (1994) 751-758.

[49] Tschaplinski T.J., Gebre G.M., Shirshac T.L., Osmotic potential of several hardwood species as affected by manipulation of throughfall precipitation in an upland oak forest during a dry year, Tree Physiol. 18 (1998) 291-298.

[50] Thomas F.M., Gausling T., Morphological and physiological responses of oak seedlings (Quercus petraea and $Q$. robur) to moderate drought, Ann. Sci. For. 57 (2000) 325-333.

[51] Tyree M.T., Ritchter H. Alternative methods of analysing water potential isotherms: some cautions and clarifications. I. The impact of non-ideality and some experimental errors, J. Exp. Bot. 32 (1981) 643-653.

[52] Valladares F., Pearcy R.W., Interactions between water stress, sunshade acclimation, heat tolerance and photoinhibition in the sclerophyll Heteromeles arbutifolia, Plant, Cell Environ. 20 (1997) 25-36.

[53] Valladares F., Pearcy R., Drought can be more critical in the shade than in the sun: a field study of carbon gain and photo-inhibition in a Californian shrub during a dry El Niño year, Plant Cell Environ. 25 (2002) 749-759

[54] Vieira Natividade J., Subericultura., Direçao Geral dos Sevi̧os Florestais e Aquicolas, Portugal, 1951.

[55] Welander N.T., Ottosson B., The influence of low light, drought and fertilization on transpiration and growth in young seedlings of Quercus robur L., For. Ecol. Manage. 127 (2000) 139-151. 